\title{
Successful Management of Fungal Mastitis in Goats - A Report of Three Cases
}

\author{
Sudhakara Reddy $\mathrm{B}^{1 *}$, Sivajothi $\mathrm{S}^{2}$ and Deepika Kumari $\mathrm{G}^{3}$ \\ ${ }^{1}$ Department of Veterinary Clinical Complex, India \\ ${ }^{2}$ Department of Veterinary Parasitology, India \\ ${ }^{3}$ Department of Veterinary Microbiology, India
}

*Corresponding author: Sudhakara Reddy B, Department of Veterinary Clinical Complex, Faculty of Veterinary Medicine, Andhra Pradesh, India Submission: 㡙January 12, 2018; Published: 監 May 29, 2018

\begin{abstract}
Three goats were treated for mastitis with an antibiotic without success, was presented to the Veterinary Hospital. was yellowish colour watery consistent and devoid of flakes and clots. Milk was processed in Sabourauds dextrose agar and it revealed the presence of yeast. Animals were treated with fluconazole @ $5 \mathrm{mg} / \mathrm{kg}$ body weight intravenously for three days along with supportive therapy. After 9 - 21 days of therapy, animals were free from abnormal milk.
\end{abstract}

Keywords: Goat; Fluconazole; Mastitis; Yeast

\section{Introduction}

Mastitis is recognized as one of the most costly diseases in dairy cattle across the world. The most common aetiological factors for mastitis are bacteria, mycoplasmas, viruses, fungi, and algae. Yeasts are main aetiological agents for the development of mycotic mastitis. Among the yeasts, the Candida sp. is the most frequent isolates [1]. Treatment of mycotic infection is problematic as compared to the bacterial infection [2]. Reports on the mastitis in goats were reported but, fungal mastitis was rare.

\section{Case History and Observations}

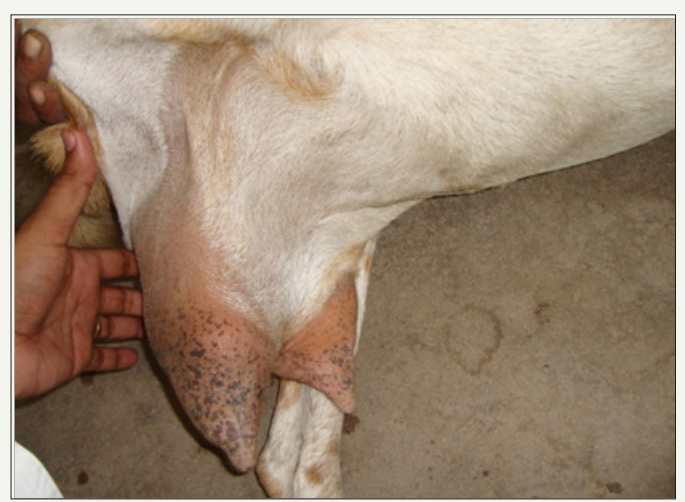

Figure 1: Goat showing the oedematous udder.

Three goats were referred to the College of Veterinary Science, Proddatur with the history of repeated mastitis since two months in spite of antibiotic therapy. Upon clinical examination, huge enlargement of udder was noticed. The udder was painful on palpation and milk was yellowish, watery in consistency, but devoid of flakes and clots (Figure 1). Milk samples were screened for mastitis by California Mastitis Test (CMT) and milk samples were also collected for microbial isolation under strict aseptic conditions [3]. Milk was inoculated in nutrient agar and also inoculated into Sabouraud Dextrose Agar (SDA).

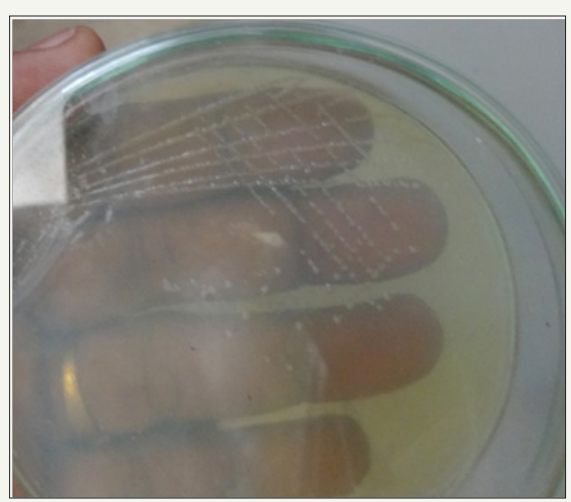

Figure 2: Fungal growth on SDA.

The colonies on the SDA were opaque, creamy and white in nature (Figure 2) [4]. Microscopic smear appeared as oval to round budding blastospores. Identification of microorganisms was done according to the standard methods [5]. This fungal isolate was also subjected to in vitro antifungal sensitivity profile and it was highly sensitive to the fluconazole. 


\section{Treatment and discussion}

Animals were treated with fluconazole inj. (@ $5 \mathrm{mg} / \mathrm{kg}$ body weight, IV) for three days followed by DNS (500ml, I.V. for two days), Maxxitol inj. (2ml, IM for three days), chlorpheniramine maleate inj. (1.5ml, IM for three days). The gradual clinical improvement was by the reduction in the size of the, hardness was resolved with normal $\mathrm{pH}$. Restoration of the normal milk was noticed after 5 to 9 days of therapy. But, complete reduction in the size of the udder was observed after days of therapy.

Due to unhygienic conditions of the animal sheds, there is a chance of increase fungal spores and hyphae in lactating animals. Teat injuries may predispose to the establishment of a yeast infection [6].

The use of such antibiotics encourages the establishment of the infection by damaging the mammary epithelium. Similarly, during this case study, it was observed that initially, the use of antibiotics worsened the condition of clinical mastitis [7]. Yeast infections of the udder are highly associated with simultaneous effects of favourable triggering factors, e.g. irritation of the milk alveoli and ducts, as well as the milk sinus due to injuries, bacterial infections or intra-udder administration of various drugs, especially longterm use of antibiotics. Immediate prompt treatment and hygienic conditions in the animal environment will prevent the damage to the udder and complications from the environmental pathogens.

\section{Summary}

Present paper the successful management of fungal mastitis in goats.

\section{Acknowledgement}

Authors are thanking full to the authorities of Sri Venkateswara Veterinary University for providing the facilities to carry out the present study.

\section{References}

1. Kimatura H, Anri A, Fuse K, Seo M, Itakura C (1990) Chronic mastitis caused by Candida maltosa in a cow. Vet Pathol 27(6): 465-466.

2. Hamza OJ, van den Bout-van den Beukel CJ, Matee MI, Moshi MJ, Mikx FH, et al. (2006) Antifungal activity of some Tanzanian plants used traditionally for the treatment of fungal infections. J Ethnopharmacol 108(1): 124-132.

3. Reddy BSS, Kumari KN, Reddy BS, Reddy YR (2014) Therapeutic management of ketosis associated with sub-clinical mastitis in transition cows. Intas Polivet 15 (2): 504-506.

4. Reddy BS, Sivajothi S, Kumari GD (2015) Diagnosis and management of oral malasseziasis in a dog. Intas Polivet 16 (2): 483-484.

5. Quinn PJ, Carter ME, Markey BK, Carter GR (1999) Veterinary Microbiology Mosby. Harcourt Publishers Limited, Europe.

6. Krukowski H, Lisowski A, Ròzanski P, Skórka A (2006) Yeasts and algae isolated from cows with mastitis in the south-eastern part of Poland. Pol J Vet Sci 9(3): 181-184.

7. Costa EO, Gandra CR, Pires MF, Coutinho SD, Castilho W (1993) Survey of bovine mycotic mastitis in dairy herds in the State of Sao Paulo, Brazil. Mycopathologia 124(1): 13-17.
Creative Commons Attribution 4.0 International License

For possible submissions Click Here

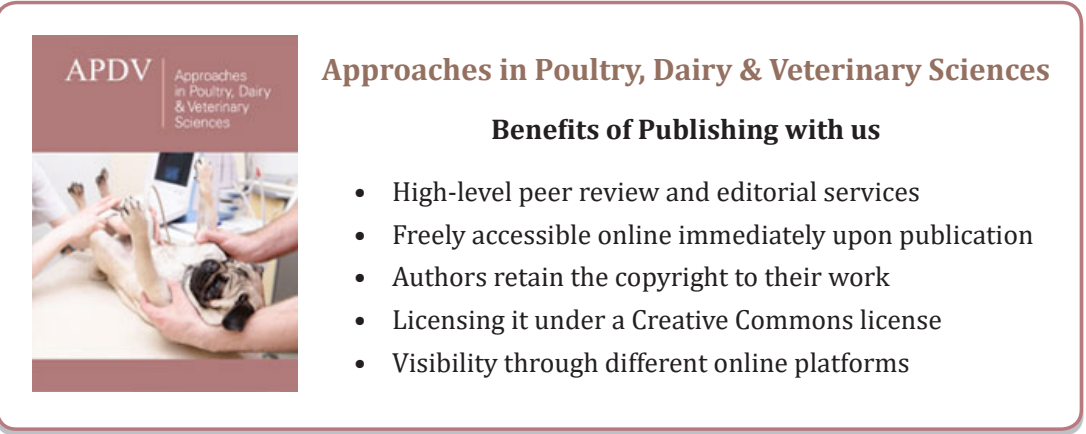

